\title{
DNA Cleavage Induced by the Reaction of Salsolinol with $\mathrm{Cu}, \mathrm{Zn}$-Superoxide Dismutase
}

\author{
Jung Hoon Kang \\ Department of Genetic Engineering, Cheongin University, Cheongin 360-764, Korea. E-mail:jhkang@chiac.kr \\ Received Jily 31,2007
}

\begin{abstract}
Salsolinol, endogenous neurotoxin, is known to be involved in the pathogenesis of Parkinson's disease (PD). In the present study, we have investigated the oxidative damage of $\mathrm{DN} \Lambda$ induced by the reaction of salsolinol with $\mathrm{Cu}, \mathrm{Zn}$-SOD. When plasmid DNA incubated with salsolinol and $\mathrm{Cu}, \mathrm{Zn}-\mathrm{SOD}$. DN $\Lambda$ cleavage was proportional to the concentrations of salsolinol and $\mathrm{Cu}, \mathrm{Zn}-\mathrm{SOD}$. The salsolinol/Cu,Zn-SOD system-mediated DN $\Lambda$ cleavage was significantly inhibited by radical scavengers such as mannitol, ethanol and thiourea. These results indicated that free radicals might participate in DN $\Lambda$ cleavage by the salsolinol/Cu,Zn-SOD system. Spectrophotometric study using a thiobarbituric acid showed that hydroxyl radical formation was proportional to the concentration of salsolinol and was inhibited by radical scavengers. These results indicated that hydroxyl radical generated in the reaction of salsolinol with $\mathrm{Cu}, \mathrm{Zn}$-SOD was implicated in the DN $\Lambda$ cleavage. Catalase and copper chelators inhibited DN $\Lambda$ cleavage and the production of hydroxyl radicals. These results suggest that DN $\Lambda$ cleavage is mediated in the reaction of $\$$ alsolinol with $\mathrm{Cu}, \mathrm{Zn}-\mathrm{SOD}$ via the generation of hydroxyl radical by a combination of the oxidation reaction of salsolinol and Fenton-like reaction of free copper ions released from oxidatively damaged SOD.
\end{abstract}

Key Words : Salsolinol, Copper,zinc-superoxide dismutase, DNA cleavage

\section{Introduction}

Salsolinol (1-methyl-6,7-dihydroxy-1,2,3,4-tetrahydroisoquinoline, Figure 1) is an endogenous catechol-derived neurotoxin supposedly related to the development of Parkinsons disease (PD) ${ }^{1+4}$ Several studies indicated that salsolinol is toxic to dopaminergic neurons in vitro as well as in vivo. Salsolinol increased the production of reactive oxygen species (ROS) and significantly decreased glutathione levels in SH-SY5Y cells."6 Among several causative factors, oxidative stress is known to be a major contributing factor to the biological cascade leading to dopamine cell degeneration in $\mathrm{PD}^{7-9}$ Furthermore, oxidative damage of biological macromolecules has been proposed to be a critical factor of the pathogenesis of various neurodegenerative disorders. ${ }^{10-12}$

A group of metalloproteins known as $\mathrm{Cu}, \mathrm{Zn}$-superoxide dismutase (SOD) catalyzes the dismutation of two superoxide anions into one oxygen and one hydrogen peroxide and thus is involved in protecting the cell from oxygen toxicity. Cu, Zn-SOD has great physiological significance and therapeutic potential. This enzyme requires $\mathrm{Cu}$ and $\mathrm{Zn}$ for its biological activity, and loss of Cu results in its complete inactivation, leading in many cases to the development<smiles>CC1NCCc2cc(O)c(O)cc21</smiles>

SALSOLINOL

Figure 1. Chemical structure of salsolinol. of human disease..$^{13,14}$ Previous reports have shown that several oxidants lead to Cu,Zn-SOD fragmentation and the release of copper ions from the enzyme. 157 Trace metal such as iron and copper, which are variously present in biological systems, may interact with $\mathrm{ROS}$, ionizing radiation, or microwave radiation to damage macromolecules. ${ }^{18-23}$ ROS may play an important role in several pathological conditions of the central nervous system, where the directly injure tissue. ROS produce tissue damage through multiple mechanisms and can worsen acute neurodegenerative disorders including PD. It has been reported that salsolinol in conjugation with copper ion undergoes redox cycling to produce ROS such as hydroxyl radicals that cause DNA strand scission and cell death. ${ }^{56}$ Recently, we have shown that salsolinol led to the fragmentation and aggregation of $\mathrm{Cu}, \mathrm{Zn}-\mathrm{SOD}{ }^{24}$ In this context, we hypothesize that $\mathrm{Cu}, \mathrm{Zn}-$ SOD could be a source of copper and oxidative stress that might trigger the oxidative damage of DNA induced by salsolinol. Although salsolinol-dependent DNA damage has been known previously, the oxidative damage of DNA by the reaction of salsolinol with $\mathrm{Cu}, \mathrm{Zn}-\mathrm{SOD}$ has not been reported.

In this study, we examined the DNA cleavage caused by salsolinol and $\mathrm{Cu}, \mathrm{Zn}-\mathrm{SOD}$. Our results indicate that salsolinol in the presence of $\mathrm{Cu}, \mathrm{Zn}-\mathrm{SOD}$ can cleave DNA through a mechanism that involves hydroxyl radical.

\section{Materials and Methods}

Materials. Recombinant human $\mathrm{Cu}, \mathrm{Zn}$-SOD was overproduced and purified as described previously. ${ }^{25}$ pUC19 plasmid DNA was prepared and purified from E. coli cul- 
tures by using QIAGEN plasmid kit (Santa Clarita, USA). Catalase, thiourea, diethyldithiocarbamic acid (DDC), and thiobarbituric acid were purchased from Sigma. Chelex 100 resin (sodium form) was obtained from Bio-Rad. All solutions were treated with Chelex 100 resin to remove traces of transition metal ions.

Analysis of DNA cleavage. Supercoiled plasmid pUC19 DNA $(0.5-1.0 \mu \mathrm{g})$ in $10 \mathrm{mM}$ potassium phosphate buffer (pH 7.4) was incubated for $2 \mathrm{~h}$ at $37^{\circ} \mathrm{C}$ with different concentrations of salsolinol and $\mathrm{Cu}, \mathrm{Zn}-\mathrm{SOD}$ in a total volume of $20 \mu \mathrm{L}$. The reaction was stopped at $-80^{\circ} \mathrm{C}$. The loading buffer $(0.25 \%$ bromophenolblue, $40 \%$ sucrose $)$ was added and samples analyzed by electrophoresis in $0.8 \%$ agarose in TBE buffer ( $2 \mathrm{mM}$ EDTA, $89 \mathrm{mM}$ boric acid and $89 \mathrm{mM}$ Tris at $\mathrm{pH} 8.3$ ). The gel was stained with ethidium bromide. Bands of DNA were detected and photographed under UV light in a dark room.

Measurement of hydroxyl radical. Detection of hydroxyl radicals was determined by measuring thiobarbituric acid reactive substance (TBARS) by a modification of the method previously described. ${ }^{25}$ An assay mixture contained $10 \mathrm{mM}$ potassium phosphate buffer ( $\mathrm{pH} \mathrm{7.4),} 10 \mathrm{mM} \mathrm{2-}$ deoxy-D-ribose, various concentrations of $\mathrm{Cu}, \mathrm{Zn}-\mathrm{SOD}$ and salsolinol in a total volume of $100 \mu \mathrm{L}$. Reaction mixtures were incubated at $37{ }^{\circ} \mathrm{C}$ for $12 \mathrm{~h}$. The degradation of 2deoxy-D-ribose was measured by addition of $2.8 \%$ trichloroacetic acid $(200 \mu \mathrm{L}), \mathrm{PBS}(200 \mu \mathrm{L})$, and $1 \%$ thiobarbituric acid $(200 \mu \mathrm{L})$, followed by heating at $100^{\circ} \mathrm{C}$ for $15 \mathrm{~min}$. After the samples were cooled to room temperature and centrifuged at $15,000 \mathrm{rpm}$ for $10 \mathrm{~min}$. Results were read by a uv/vis spectrophotometer (Shimadzu, UV-1601) at $532 \mathrm{~nm}$. All solutions used in the present experiments were treated with Chelex 100.

Replicates. Unless otherwise indicated, each result described in this paper is representative of at least three separate experiments.

\section{Results and Discussion}

When DNA was incubated in a mixture of salsolinol and $\mathrm{Cu}, \mathrm{Zn}-\mathrm{SOD}, \mathrm{DNA}$ cleavage became apparent at $0.1 \mathrm{mM}$ salsolinol and $1 \mu \mathrm{M} \mathrm{Cu}, \mathrm{Zn}-\mathrm{SOD}$; the cleavage increased up to $1 \mathrm{mM}$ salsolinol and $15 \mu \mathrm{M} \mathrm{Cu}, \mathrm{Zn}-\mathrm{SOD}$ (Fig. 2). Plasmid DNA remained intact after incubation with $15 \mu \mathrm{M} \mathrm{Cu}, \mathrm{Zn}$ SOD or $1 \mathrm{mM}$ salsolinol alone (data not shown). The participation of free radicals in the DNA damage by the salsolinol/Cu, Zn-SOD system was studied by examining the protective effect of radical scavengers. When plasmid DNA was incubated with salsolinol and $\mathrm{Cu}, \mathrm{Zn}-\mathrm{SOD}$ in the presence of mannitol, ethanol and thiourea at $37^{\circ} \mathrm{C}$ for $2 \mathrm{~h}$, all scavengers significantly prevented DNA cleavage (Fig. 3, lane 3-5). The ability of radical scavengers to protect DNA from damage indicates that the free radicals participate in the mechanism of DNA strand break produced by salsolinol and $\mathrm{Cu}, \mathrm{Zn}-\mathrm{SOD}$.

Cellular metabolism has been shown to generate oxygen species such as hydrogen peroxide, hydroxyl radical, and
(A)

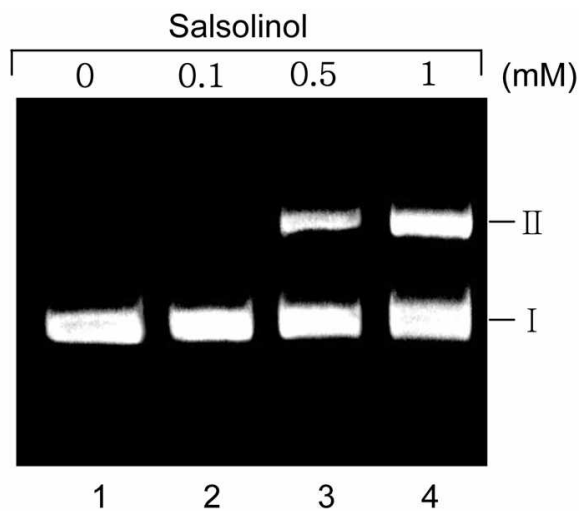

(B)

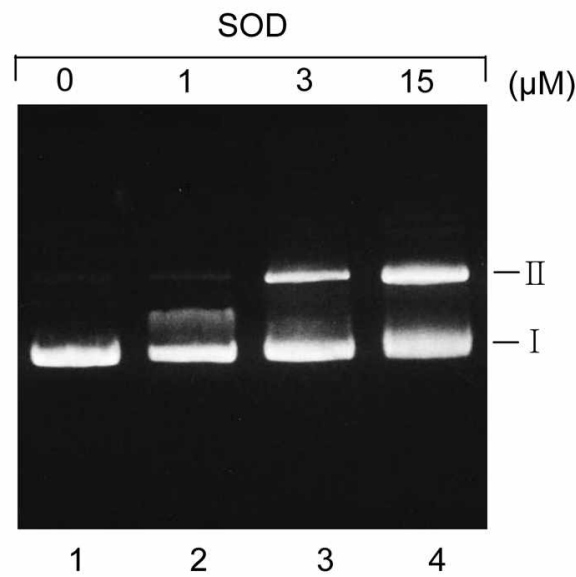

Figure 2. DNA cleavage after incubation with $\mathrm{Cu}, \mathrm{Zn}-\mathrm{SOD}$ and salsolinol. pUC $19 \mathrm{DNA}(2 \mu \mathrm{g})$ was incubated with various concentrations of $\mathrm{Cu}, \mathrm{Zn}-\mathrm{SOD}$ and salsolinol in $10 \mathrm{mM}$ potassium phosphate buffer $\left(\mathrm{pH} \mathrm{7.4)}\right.$ at $37^{\circ} \mathrm{C}$ for $2 \mathrm{~h}$. (A) Plasmid DNA was incubated with $0.1-1 \mathrm{mM}$ salsolinol, $15 \mu \mathrm{M}$ Cu,Zn-SOD. Lane 1, no addition; lane 2, 0.1 mM; lanc 3,0.5 $\mathrm{mM}$; lane 4, $1 \mathrm{mM}$ salsolinol. (B) Plasmid DNA was incubated with I mM salsolinol, 1-15 $\mu \mathrm{M}$ Cu,Zn-SOD. Lane 1, no addition; lane 2, $1, \mathrm{MA}$ lane 3, 3 $\mu \mathrm{M}$ : lane $4,15 \mu \mathrm{M} \mathrm{Cu}, \mathrm{Zn}-\mathrm{SOD}$. Reaction was stopped at $-80^{\circ} \mathrm{C}$, loading buffer was added, and the sample analyzed by clectrophoresis in $0.8 \%$ agarose. I and II indicate the position of the supercoiled and circular DNA plasmid forms, respectively.

superoxide radical. ${ }^{26}$ Trace metals such as copper and iron which are present in biological systems may interact with hydrogen peroxide, to damage biological molecules including DNA. ${ }^{18-23}$ Mixtures of copper ions and $\mathrm{H}_{2} \mathrm{O}_{2}$ have been shown to produce extensive strand breakage in DNA. ${ }^{22,27}$ Strand breakage often occurs near guanine residues, and it has been suggested that copper ions bind to DNA at these sites. $^{22}$ Several authors have suggested that copper ions could stimulate the Fenton-like reaction to produce hydroxyl radicals, which mediates DNA strand breakage. ${ }^{29-31}$ We have investigated the participation of copper ions in the salsolinol/ $\mathrm{Cu}, \mathrm{Zn}-\mathrm{SOD}$-mediated DNA strand breaks. When DNA was incubated with salsolinol and $\mathrm{Cu}, \mathrm{Zn}-\mathrm{SOD}$ in the presence of copper specific chelator, DDC, DNA cleavage was significantly inhibited (Fig. 3, lane 6). The result indicated that copper jons was involved in the DNA cleavage by the salsolinol/Cu,Zn-SOD system.

Autoxidation of a neurotoxin, 6-hydroxydopamine, leads 


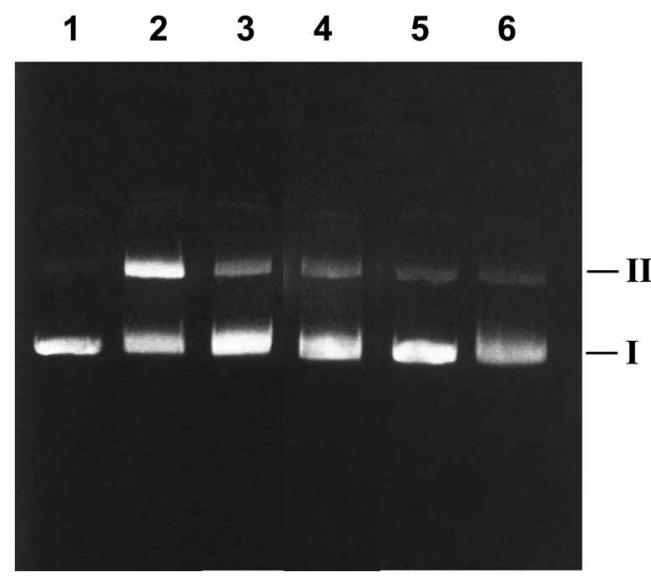

Figure 3. Effect of radical scavengers and copper chelators on the DNA cleavage by the reaction of $\mathrm{Cu}, \mathrm{Zn}-\mathrm{SOD}$ with salsolinol. $\mathrm{pUC}$ 19 DNA was incubated with Cu,Zn-SOD $(15 \mu \mathrm{M})$ and $1 \mathrm{mM}$ salsolinol in potassium phosphate buffer $(\mathrm{pH} 7.4)$ at $37^{\circ} \mathrm{C}$ for $2 \mathrm{~h}$, in the absence and the presence of $100 \mathrm{mM}$ scavengers or $5 \mathrm{mM}$ copper chelator at $37^{\circ} \mathrm{C}$. Lane 1, plasinid alone; lane 2, no addition of scavenger; lane 3, mannitol; lane 4, ethanol; lane 5, thiourea; lane 6, DDC. Agarose gel electrophoresis was performed in $0.8 \%$ agarose. I and II indicate the position of the supercoiled and circular DN $\Lambda$ plasmid forns, respectively.

to produce hydrogen peroxide and hydroxyl radicals. ${ }^{32}$ Hydroxyl radical is the most powerful oxidant and is able to damage macromolecules. ${ }^{2012}$ Recently, we reported that the fragmentation of $\mathrm{Cu}, \mathrm{Zn}$-SOD was induced by salsolinol and might lead to the releasing of copper ions from the protein. ${ }^{2+}$ The previous results have been suggested that the copper releasing of $\mathrm{Cu}, \mathrm{Zn}-\mathrm{SOD}$ by salsolinol might be closely associated with the modification of $\mathrm{Cu}, \mathrm{Zn}-\mathrm{SOD}$. X-ray crystallographic studies on $\mathrm{Cu}, \mathrm{Zn}-\mathrm{SOD}$ have shown three histidine side chains (His-46, His-48, His-120) to coordinated to the copper and two histidine (His-74, His-80) and one aspartic acid (Asp-83) residues to the zinc ion. ${ }^{33}$ Thus, it was suggested that copper binding sites might be modified during the reaction of $\mathrm{Cu}, \mathrm{Zn}-\mathrm{SOD}$ with salsolinol. Consequently, copper became almost free form the ligand and was released from the oxidatively damaged enzyme. It has been reported that the induction of DNA damage by salsolinol and copper ion might be due to the generations of hydrogen peroxide and hydroxyl radicals. ${ }^{5}$ Therefore, the present results suggested that early oxidation of salsolinol is participated in the releasing of copper ions from $\mathrm{Cu}, \mathrm{Zn}$-SOD and the generation of hydrogen peroxide. The subsequent interaction of free copper ions and hydrogen peroxide in the Fenton-like reaction will yield hydroxyl radical. Evidence that catalase protected the DNA cleavage induced by the salsolinol/Cu,Zn-SOD system supports this mechanism (Fig. 4).

The generation of hydroxyl radicals in the salsolinol/ $\mathrm{Cu}, \mathrm{Zn}-\mathrm{SOD}$ system was measured with thiobarbituric acidreactive substance (TBARS). The level of hydroxyl radicals were increased in a salsolinol concentration-dependent manner (Fig. 5). Radical scavengers inhibited the formation of hydroxyl radicals in salsolinol/Cu,Zn-SOD system (Table

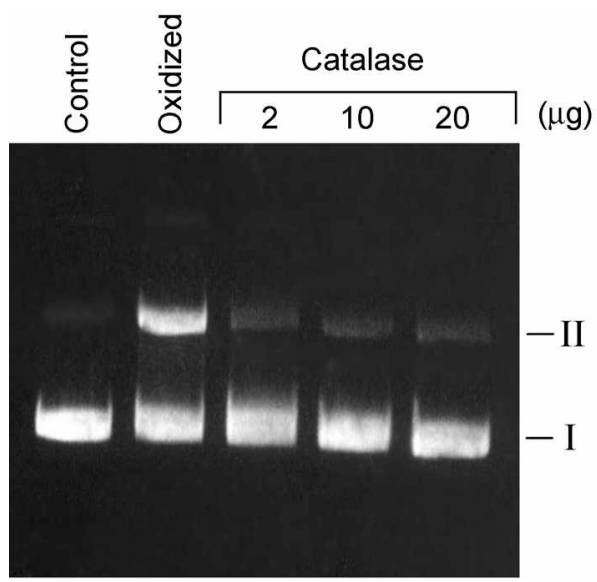

Figure 4. Effect of catalase on the DNA cleavage by the reaction of Cu,Zn-SOD with salsolinol. pUC 19 DNA was incubated with Cu,Zn-SOD $(15 \mu \mathrm{M})$ and I inM salsolinol potassium phosphate buffer $(\mathrm{pH} 7.4)$ at $37^{\circ} \mathrm{C}$ for $2 \mathrm{~h}$ in various concentrations of catalase. Lane 1, plasmid alone; lane 2, no addition of catalase; lane $3,2 \mu \mathrm{g}$ catalase; lane $3,10 \mu \mathrm{g}$ catalase; lane $4,20 \mu \mathrm{g}$ catalase. Agarose gel clectrophoresis was performed in $0.8 \%$ agarose. I and II indicate the position of the supercoiled and circular DNA plasinid forms, respectively.

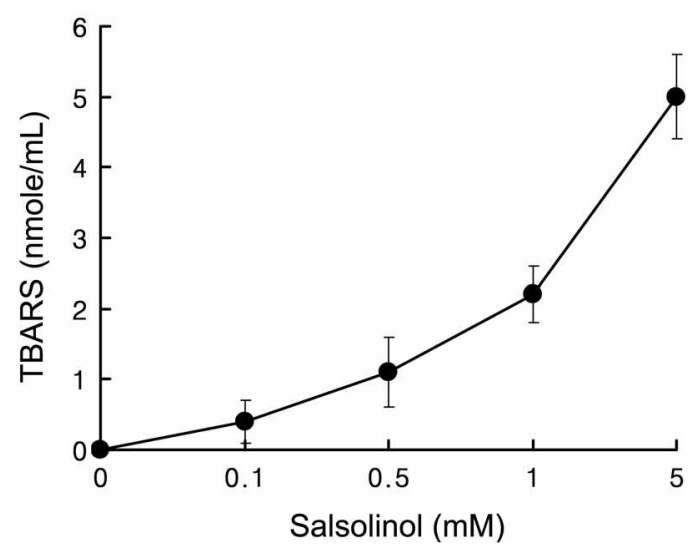

Figure 5. Generation of hydroxyl radical during the reaction of Cu,Zn-SOD with salsolinol. The reaction mixtures contained 10 $\mathrm{mM}$ 2-dcoxy-D-ribose, $15 \mu \mathrm{M} \quad \mathrm{Cu}, \mathrm{Zn}-\mathrm{SDOD}$ and various concentration of salsolinol in $10 \mathrm{mM}$ phosphatc buffer at $\mathrm{pH} 7.4$ for $12 \mathrm{~h}$. The degradation of 2-deoxy-D-ribose was measured by adding $200 \mu \mathrm{L}$ of PBS, $200 \mu \mathrm{L}$ of $2.8 \%$ (w/v) trichloroacetic acid, $200 / \mathrm{L}$ of $1 \%(\mathrm{w} / \mathrm{v})$ thiobarbituric acid, followed by heating at 100 ${ }^{\circ} \mathrm{C}$ for $10 \mathrm{~min}$. $\Lambda$ fter cooling, the absorbance at 532 nun was measured. Data represent the means \pm S.D. $(n=4-5)$.

1). The result supports our finding that free radicals may be involved in salsolinol/Cu,Zn-SOD-mediated DNA cleavage. It has been reported that copper concentration was significantly increased in the cerebrospinal-fluid of Parkinson's disease and Alzheimer's disease. ${ }^{34,35}$ These results suggested that copper-catalyzed oxidative reaction might contribute to the pathogenesis of neurodegenerative disorders. Copper chelator significantly inhibited the generation of hydroxyl radicals by the salsolinol/Cu, $\mathrm{Zn}$-SOD system (Table 1 ). The result suggests that redox reactions of copper may facilitate the generation of hydroxyl radical. 
Table 1. Effect of radical scavengers and copper chelator on the formation of hydroxyl radicals by salsolinol and Cu,Zn-SOD

\begin{tabular}{lcc}
\hline $\begin{array}{c}\text { Scavenger/chelator } \\
(\mathrm{mM})\end{array}$ & $\begin{array}{c}\text { TBARS } \\
\text { (nmole/mL) }\end{array}$ & $\begin{array}{c}\text { nhibition of formation of } \\
\text { TBARS (\%) }\end{array}$ \\
\hline No addition & $2.18 \pm 0.2$ & \\
Mannitol (100) & $0.32 \pm 0.1$ & $85 \pm 4.6$ \\
Ethanol (100) & $1.20 \pm 0.2$ & $52 \pm 9.2$ \\
Thiourea (20) & $0.36 \pm 0.1$ & $84 \pm 5.1$ \\
DDC (5) & $0.56 \pm 0.1$ & $74 \pm 5.9$ \\
\hline
\end{tabular}

Reaction mixture containing $15 \mu \mathrm{M}$ Cu,Zn-SOD, $1 \mathrm{mM}$ salsolinol in 10 $\mathrm{mM}$ potassium phosphate buffer at pII 7.4 , in the presence of each scavenger and copper chelatot.

In conclusion, the present results indicated that DNA cleavage was induced by the reaction of salsolinol/Cu, $\mathrm{Zn}$ SOD involving hydroxyl radical generation from hydrogen peroxide. The hydroxyl radicals were generated by a combination of the autoxidation of salsolinol and the Fenton-like reaction of free copper ions released from oxidatively damaged SOD. It would be expected that the cellular radical detoxification system, including SOD, would be capable of handling increased radical levels. Interestingly, SOD activity is increased in discrete brain regions in different neurodegenerative disorders; in $\mathrm{PD}$, it is characteristically increased in the subtantia nigra. ${ }^{36,37}$ Therefore, DNA damage by the salsolinol/Cu,Zn-SOD system could be relatively favored in diseases where $\mathrm{Cu}, \mathrm{Zn}$-SOD concentration is elevated such as $\mathrm{PD}$ and other neurodegenerative disorders.

\section{References}

1. Ikeda, H.; Markey, C. J.; Markey, S. P. Brain Res. 1993, 575, 285.

2. Moser, A.; Kompf, D. Life Sci. 1992, 50, 1885.

3. Niwa, T.; Takeda, T.; Yoshizumi, H.; Tatematsu, A.; Yoshida, M.; Dosterdi, P:; Naoi, M.; Nagatsu, T. Biochem. Biophys. Res. Commun, 1991, 177, 603.

4. Ohta, S.; Kohno, M.; Makino, Y.; Tachikawa, O.; Hirobe, M. Biomed. Res. 1987, 8, 453 .

5. Kim, H. J.; Yoon, H. R.; Washington, S.; Chang, I. I.; Oh, Y. J.; Surh, Y. J. Netrosci. Lett, 1997, 238, 95

6. Kim, H. J.; Soh, Y.; Jang, J. H.; Lee, J. S.; Oh, Y. J.; Surh, Y. J. Mol. Pharmacol. 2001, 60, 440.

7. Ebadi, M. Methods Enzymol. 1991, 205, 363.

8. Ebadi, M.; Kumari, M. V. R.; Hiramatsu, M.; Hao, R.; Pfeiffer, R.
F.; Rojas, P. Restor: Neurol, Neurosci, 1998, 12, 103.

9. Kumari, M. V. R.; Hiramatsu, M.; Ebadi. M. Cell Mol. Biol. 2000. 46,627 .

10. Bowling. A. C.; Schulz, J. B.; Brown, R. H. Jr.; Beal, M. F. Neurochem, 1993, 61, 2322.

11. Hensley, K.; Carney, J. M.; Mattson, M. P.; Aksenova, M.; Harris, M.; Wu, J. F.; Floyd, R. A.; Butlerfield, D. A. Proc. Natl Acad. Sci. USA 1994, 91, 3270.

12. Jenner, P.; Dexter, D. T.; Sian, J.; Schapira, A. H.; Marsden, C. D. Am. Netral. 1992, 32, Suppl: 582.

13. Thara, Y; Nobukuni, K.; Takata, H.; Hayabara, T. Netwol. Res. $2005,27,105$

14. Kim, K. S.; Choi, S. Y; Kwon, H. Y.; Won, M. H.; Kang, T. C.; Kang. J. H. Free Radical. Biol. Med. 2002, 32, 544.

15. Choi. S. Y.; Kwon, H. Y.; Kwon, O. B.; Kang. J. H. Biochim. Biophys, Acta 1999, 1472,651.

16. Kang, J. H.; Kim, S. M. Mol. Cells 1997, 7, 553.

17. Kim, S. M.; Kang J. H. Mol. Cells 1997, 7, 120.

18. Goldstein, S.; Czapski, G J. Ant. Chent. Soc. 1986, J08, 2244.

19. Gutteridge, J. M. C.; Halliwell, B. Biochen. Pharmacol 1982, 31, $280 \mathrm{l}$.

20. Imlay, J. A.; Chin, S. M.; Linn, S. Science 1988, 240,640.

21. Prulz, W. A. Radiat. Environ. Biophys, 1984, $23,7$.

22. Sagripanti, J.-L.; Kraemer, K. H. J. Biol. Chem, 1989, 264, 1729.

23. Sagripanti, J. L.; Swicord, M. L.; Davis, C. C. Radiat. Res, 1987, Ho, 219 .

24. Kang, J. H. J. Biochent. Mol. Biol. 2007, 40,684.

25. Kang. J. H. Bull. Korean Chem. Soc. 2005, 26, 1251.

26. Cerruti, P. A. Science 1984, 227, 375.

27. Feldberg, R. S.; Carao, J. A.; Paradise, R. J. Free Radic. Biol. Med, 1985, 1,459 .

28. Chiou, S. H. J. Biochent. (Tokyo) 1983, 94, 1259.

29. Reed, C. J.; Douglas, K. T. Biochem. Biophys. Res. Conmtin. 1989. 162 . I111.

30. Rowley, D. A.; Halliwell, B. Aich. Biochem. Biophys. 1983, 225 , 279.

31. Stoewe, R. S.; Prutz, W. A. Free Radical Biol. Med. 1987, 3, 97.

32. Bindoli, A.; Rigobello, M. P.; Deeble, D. J. Free Radic. Bio. Med. 1992. 13.391.

33. Tainer, J. A.; GertzofT, E. D.; Richardson, J. S.; Richardson, D. C. Nature 1983, 306, 284.

34. Pall, H. S.; Williams, A. C.; Blake, D. R.; Lunec, J.; Gutteridge, J. M.; Hall, M.; Taylor, A. Lancet. 1987, 2, 238.

35. Multhaup, G.; Schlicksupp, A.; Hesse, L.; Behler, D.; Ruppert, T.; Masters, C. L.; Beyreuther, K. Science 1996, 271, 1406.

36. Martilla, R. J.; Lorezo, H.; Rinne, U. K. J. Nemrol Sci. 1988, 86, 32.

37. Saggu, H.; Cooksey, J.; Dexter, D.; Wells, F. R.; Lees, A.; Jenner, P.; Marsden, C. D. J. Netrochen. 1989, 53, 692. 